\title{
Risk factors associated with delay in diagnosis and mortality in patients with COVID-19 in the city of Rio de Janeiro, Brazil
}

\author{
Fatores de risco associados ao atraso no diagnóstico e mortalidade \\ em pacientes com COVID-19 na cidade do Rio de Janeiro, Brasil
}

\author{
Alexandre de Fátima Cobre (https://orcid.org/0000-0001-6642-3928) ${ }^{1}$ \\ Beatriz Böger (https://orcid.org/0000-0003-0025-2315) ${ }^{1}$ \\ Mariana Millan Fachi (https://orcid.org/0000-0001-5918-4738) ${ }^{1}$ \\ Raquel de Oliveira Vilhena (https://orcid.org/0000-0002-8942-0591) ${ }^{1}$ \\ Eric Luiz Domingos (https://orcid.org/0000-0001-8474-3984) ${ }^{1}$ \\ Fernanda Stumpf Tonin (https://orcid.org/0000-0003-4262-8608) ${ }^{1}$ \\ Roberto Pontarolo (https://orcid.org/0000-0002-7049-4363) ${ }^{1}$
}

${ }^{1}$ Programa de PósGraduação em Ciências Farmacêuticas, Departamento de Farmácia, Universidade Federal do Paraná. Av. Lothário Meissner 632, Jardim Botânico. 80210170 Curitiba PR Brasil. alexandrecobre@gmail.com
Abstract We investigated the predictors of delay in the diagnosis and mortality of patients with COVID-19 in Rio de Janeiro, Brazil. A cohort of 3,656 patients were evaluated (Feb-Apr 2020) and patients' sociodemographic characteristics, and social development index (SDI) were used as determinant factors of diagnosis delays and mortality. Kaplan-Meier survival analyses, time-dependent Cox regression models, and multivariate logistic regression analyses were conducted. The median time from symptoms onset to diagnosis was eight days (interquartile range [IQR] 7.238.99 days). Half of the patients recovered during the evaluated period, and $8.3 \%$ died. Mortality rates were higher in men. Delays in diagnosis were associated with male gender $(p=0.015)$ and patients living in low SDI areas $(p<0.001)$. The age groups statistically associated with death were: $70-79$ years, $80-89$ years, and $90-99$ years. Delays to diagnosis greater than eight days were also risk factors for death. Delays in diagnosis and risk factors for death from COVID-19 were associated with male gender, age under 60 years, and patients living in regions with lower SDI. Delays superior to eight days to diagnosis increased mortality rates.

Key words COVID-19, Multivariate analysis, Mortality
Resumo Investigamos os preditores de atraso no diagnóstico e mortalidade de pacientes com $\mathrm{CO}-$ VID-19 no Rio de Janeiro, Brasil. Uma coorte de 3.656 pacientes foi avaliada (fevereiro-abril de 2020) e as características sociodemográficas dos pacientes, o bairro e o indice de desenvolvimento social (IDS) foram usados como fatores determinantes dos atrasos no diagnóstico e da mortalidade. Foram realizadas análises de sobrevivência de Kaplan-Meier, modelos de regressão Cox dependentes do tempo e análises de regressão logística multivariada. O tempo mediano desde o início dos sintomas até o diagnóstico foi de oito dias (intervalo interquartil [IQR] 7,23-8,99 dias). Metade dos pacientes se recuperou no período avaliado e 8,3\% faleceram. As taxas de mortalidade foram maiores nos homens. Atrasos no diagnóstico foram associados ao sexo masculino $(p=0,015) e$ pacientes que moravam em áreas com baixo IDS $(p<0,001)$. As faixas etárias estatisticamente associadas à morte foram: 70-79 anos, 80-89 anos e 90-99 anos. Atrasos no diagnóstico superiores a oito dias também foram fatores de risco para óbito. Atrasos no diagnóstico e fatores de risco para morte por COVID-19 foram associados ao sexo masculino, idade abaixo de 60 anos e pacientes que vivem em regiões com menor IDS. Atrasos superiores a oito dias no diagnóstico aumentam as taxas de mortalidade.

Palavras-chave COVID-19, Análise multivariada, Mortalidade 


\section{Introduction}

The emergence of severe acute respiratory syndrome coronavirus 2 (SARS-CoV-2) in China at the end of 2019 has caused a sizeable global outbreak. It is a major public health issue responsible for more than 603,697 deaths and more than five million infected people worldwide ${ }^{1}$. The first case of this disease, called COVID-19, in South America, was from a 61-year-old Brazilian diagnosed at the Albert Einstein Hospital in São Paulo (Brazil) after returning from a trip to northern Italy in February $2020^{2,3}$. Since this episode, more than 2,098,389 cases and 79,488 deaths have been confirmed in Brazil, framing the country in a public health state of emergency of international interest, according to the World Health Organization $(\mathrm{WHO})^{1}$.

The virus is transmitted human-to-human via droplets or direct contact, with a mean incubation period of infection of 6.4 days $^{4}$. Among patients with pneumonia associated with COVID-19, fever is the most common symptom, followed by cough and difficulty breathing. Bilateral lung involvement with ground-glass opacity is the most common finding from computed tomography images of the chest. However, most patients may be asymptomatic and still transmit the virus even before the onset of symptoms ${ }^{1,4}$. Studies demonstrated that the virus is detectable for some time on smooth surfaces, aerosols, and feces ${ }^{4}$.

Currently, the gold standard for confirming suspected cases of the COVID-19 is reverse transcription-polymerase chain reaction (RT-PCR). This test detects viral nucleic acid for laboratory diagnosis ${ }^{5}$. Additional methods, such as serological tests, in which the virus antigens or antibodies produced are investigated, can also confirm the diagnosis ${ }^{6,7}$. Large-scale testing, rapid diagnosis, and immediate case isolation, associated with rigorous screening and preventive measures of social distance, and basic hygiene, are essential procedures to reduce the spread of COVID-191,8.

Rio de Janeiro, the second-largest city in Brazil with important industrial and touristic flows, is one of the areas with the highest number of cases $(n>66,909)$ and deaths $(n>7,703)$ by COVID-199-11. In this city, much of the population is concentrated into clusters known as favelas, where the susceptibility to infections is high. This occurs due to the absence or scarcity of basic sanitation (i.e., lack of drinking water, toilets, sewage, garbage collection, and safe housing), as well as space restrictions, overcrowding, and vio- lence, which inhabitants from properly following the COVID-19 preventive measures ${ }^{4,9,12}$.

Thus, considering the current pandemic situation worldwide with an important emphasis on underdeveloped regions, our aim was to investigate the risk factors associated of delay in the diagnosis and mortality of patients with COVID-19 in Rio de Janeiro, Brazil.

\section{Methods}

\section{Study design and data collection}

This retrospective cohort study included patients diagnosed with COVID-19 in Rio de Janeiro, located in the southwest region of Brazil, which represents approximately $3.0 \%$ of the Brazilian population.

Data were obtained from the Painel Rio COVID-19 database ${ }^{13}$, maintained by the City Hall of Rio de Janeiro. We included all patients (irrespective of age or gender) with a positive diagnosis for COVID-19 from February 27, 2020 to April 26, 2020. Patients' social development index (SDI) were classified according to the addresses of Rio de Janeiro ${ }^{14}$ into two groups: low social index and high social index. The time for diagnosis (in days) was estimated by the difference between the date of the onset of the first symptoms of COVID-19 and the date of diagnosis. For the analysis of predictors of diagnosis delays, the independent variables were age group, sex, SDI, and evolution of the disease. The dependent variable was the time to diagnosis.

In our analysis of risk factors associated with COVID-19 mortality, the independent variables were age group, sex, SDI, and time to diagnosis. In this case, the dependent variable, mortality, was binary and categorized as 'dead' or 'alive'. Patients with the active disease were considered alive.

\section{Statistical analyses}

A descriptive analysis was performed using the median and interquartile range (IQR) for continuous variables with a non-normal probability distribution, and the frequency for categorical variables.

The Kaplan-Meier method was adopted to estimate the delay in diagnosis. The log-rank test was used to compare the Kaplan-Meier survival curves of the independent variables. Both univariate and multivariate time-dependent Cox re- 
gression models were used to investigate the risk factors associated with the delay in diagnosis. The hazard $\mathrm{ratio}^{7}$ and corresponding 95\% confidence interval (CI) were used to quantify the size of the effects of risk factors.

In relation to mortality data, the initial objective was to investigate the prognostic factors for the time until death by COVID 19 using the Cox regression survival analysis method, however, given the lack of information on patient's follow-up time (e.g. date from disease diagnosis to death, cure, or loss of follow-up) in the original database, it was not possible to use the method of survival analysis. Therefore, to evaluate COVID-19 mortality risk factors, bivariate analysis was performed using the Custom Table function of the SPSS Software (IBM, USA) a preparatory phase of the multivariate analysis, which allowed for determining the correlation of possible independent variables that may influence the disease outcome. The multivariate analysis of logistic regression was used to investigate the risk factors related with mortality due to COVID-19. In addition, sensitivity analysis (univariate and multivariate) was performed, excluding patients with active disease. The odds ratio (OR) and corresponding $95 \%$ CI were used to quantify the size of the effects of risk factors. The chi-squared test was used to investigate associations between the independent and dependent variables. All statistical analyses were conducted in SPSS version 20, and the threshold for significance was set at 5.0\% $(\mathrm{p}<0.05)$.

\section{Results}

Between February and April 2020, the number of registered patients with a positive result for COVID-19 in Rio de Janeiro was 3,656; most were men $(53.1 \%)$ over the age of 40 years $(23.2 \%)$. Most patients (about 75.0\%; $\mathrm{n}=2,738$ ) lived in regions with a low social development index (SDI), including favelas (i.e., Complexo do Alemão, Rocinha, Jacarezinho, Cose Barros). The remaining patients $(n=918)$ were from regions with a high SDI (i.e., Barra da Tijuca, Botafogo, Copacabana, Ipanema, Leblon, and Tijuca). Around $50.0 \%$ of the patients $(\mathrm{n}=1,775)$ recovered during the evaluated period, $43.1 \%$ ( $\mathrm{n}=$ $1,577)$ still had the active disease, and $8.3 \%(\mathrm{n}=$ 304) died (Table 1).

We included all 3,656 patients in our analysis of the time to diagnosis (no censored nor truncated events). The median time to diagnosis was eight days (IQR, 7.236-8.997), with significant differences between males (8.0 days [IQR, 7.487-8.598]) and females (7.0 days [IQR, 6.5577.595]) (log-rank, $\mathrm{p}=0.027)$. The age of the patients had a significant effect on the time until diagnosis ( $\log$ rank, $\mathrm{p}=0.009$ ). Young patients aged 10-19 years (18.3 days [IQR, 15.6-20.9]), 20-29 years (13.5 days [IQR, 11.2-15.8]), 30-39 years (12.3 days [IQR, 10.6-14.0]), had longer median times until diagnosis than patients of advanced age between 40-49 years (7.0 days [IQR, 6.0-7.9]), 50-59 years (6.0 days [IQR, 4.9-4.9]), 60-69 years old (6.0 days [95\% CI, 4.9-7.0]), 70-79 years old (6.0 days [IQR, 4.8-7.1]), 80-89 years (4.0 days [IQR, 1.4-6.5]) and 90-99 years (2.0 days [IQR, 1.0-5.2]). Differences were also observed between SDI (log-rank, $\mathrm{p}<0.001)$. Patients from regions of a low SDI had longer delays in diagnosis (median $=7.97$ days [IQR, 7.5308.410]) when compared to those coming from more developed areas $($ median $=6.42$ days $[\mathrm{IQR}$, 5.67-7.18]) (Figure 1). The evolution of the disease also had a significant effect on the time until diagnosis ( $\log$ rank, $\mathrm{p}<0.001)$. Recovered patients (6.1 days [IQR, 5.2-6.9]) had a short median time until diagnosis than dead patients (17.3 days [IQR, 14.9-19.7]) and patients still with the active disease (19.7 days [IQR, 18.3-21.1]).

The factors associated with the time until diagnosis were investigated using the time-dependent covariate Cox regression model, because previous analysis of covariates demonstrated 'age' as not having proportional risks. The results of the Cox regression multivariate analyses revealed that males $(\mathrm{HR}=0.846$ [95\% CI, 0.739-0.968]; $\mathrm{p}$ $=0.015)$, patients living in regions with a low SDI $(\mathrm{HR}=0.721$ [95\% CI, 0.614-0.847]; $\mathrm{p}=0.000)$, patients with active disease $(\mathrm{HR}=1.960[95 \% \mathrm{CI}$, 1.574-2.440]; $\mathrm{p}=0.000$ ) had longer delays in diagnosis. The age groups that were associated with shorter time to diagnosis were: $40-49$ years (HR $=1.124$ [95\% CI, 0.875-1.446]; $\mathrm{p}=0.036), 50$ 59 years $(\mathrm{HR}=1.147$ [95\% CI, 0.867-1.519]; $\mathrm{p}=$ $0.033), 60-69$ years $(\mathrm{HR}=1.266[95 \% \mathrm{CI}, 0.932$ $1.720] ; \mathrm{p}=0.013), 70-79$ years $(\mathrm{HR}=1.200[95 \%$ CI, $0.840-1.713]$; $\mathrm{p}=0.016), 80-89$ years $(\mathrm{HR}=$ 1.160 [95\% CI, 0.773-1.739]; $\mathrm{p}=0.007)$, and 9099 years $(\mathrm{HR}=1.762$ [95\% CI, 0.771-4.027]; $\mathrm{p}=$ $0.019)$. Similar results were found in the univariate analyses (Table 2 ).

Regarding the disease outcome according to patients' gender, more men died from COVID-19 $(5.0 \% ; \mathrm{n}=182 ;)$ compared to women $(3.3 \% ; \mathrm{n}=$ $122)$. The recovery rate was also higher in women $(25.1 \% ; n=919)$ than in men $(22.5 \% ; n=$ 
Table 1. Characteristics of patients with COVID-19 in Rio de Janeiro, Brazil (February-April 2020).

\begin{tabular}{|c|c|c|}
\hline Characteristics & $\begin{array}{c}\text { Frequency } \\
\text { (n) }\end{array}$ & $\begin{array}{c}\text { Percentage } \\
(\%)\end{array}$ \\
\hline \multicolumn{3}{|l|}{ Gender } \\
\hline Female & 1940 & 53.1 \\
\hline Male & 1677 & 45.9 \\
\hline Not informed & 39 & 1.1 \\
\hline \multicolumn{3}{|l|}{ Age (years) } \\
\hline $0-9$ & 22 & 0.6 \\
\hline $10-19$ & 16 & 0.4 \\
\hline $20-29$ & 314 & 8.6 \\
\hline $30-39$ & 825 & 22.6 \\
\hline $40-49$ & 850 & 23.2 \\
\hline $50-59$ & 607 & 16.6 \\
\hline $60-69$ & 413 & 11.3 \\
\hline $70-79$ & 268 & 7.3 \\
\hline $80-89$ & 220 & 6.0 \\
\hline $90-99$ & 29 & 0.8 \\
\hline Not informed & 92 & 2.5 \\
\hline \multicolumn{3}{|l|}{ SDI } \\
\hline Low SDI & 2738 & 74.9 \\
\hline High SDI & 918 & 25.1 \\
\hline \multicolumn{3}{|c|}{$\begin{array}{l}\text { Time between symptoms } \\
\text { onset and diagnosis (days) }\end{array}$} \\
\hline$<8$ & 3279 & 89.7 \\
\hline$>8$ & 377 & 10.3 \\
\hline \multicolumn{3}{|l|}{ Disease evolution } \\
\hline Recovered & 1775 & 48.6 \\
\hline Death & 304 & 8.3 \\
\hline Active disease & 1577 & 43.1 \\
\hline
\end{tabular}

182) (Chi-squared test, $\mathrm{p}<0.001$ ). Still, $24.6 \%$ $(n=899)$ of women and 18.4\% $(n=674)$ of men had the active disease (Table 3 ). There was also a significant association between the disease outcome and age $(\mathrm{p}<0.001)$. Higher death rates were found in older age groups: patients aged 2029 years died less frequently $(0.1 \%)$ compared to groups between $70-79$ years $(1.8 \%)$ and 80 89 years $(2.0 \%)$. The highest rates of recovery were recorded for patients between 30-39 years of age $(11.4 \%)$, while these rates were extremely low $(0.2 \%)$ for patients aged $90-99$ years. The age group of 40-49 years had the highest number of patients with active disease (11.5\%). A statistically significant association was found between the disease outcome and the patients' SDI $(\mathrm{p}<$ 0.001 ). Although patients living in neighborhoods with a lower SDI had with a higher number of deaths compared to those from a high

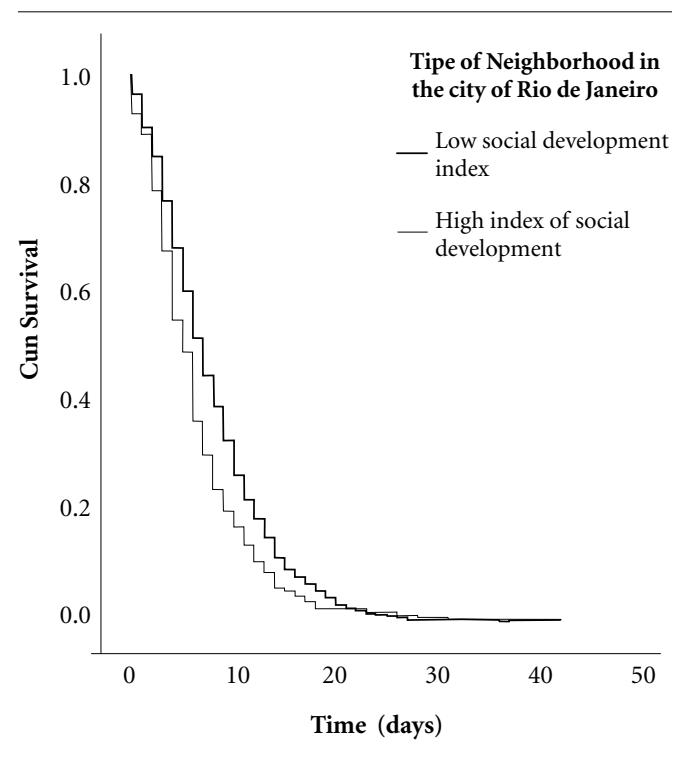

Figure 1. Kaplan-Meier curve by Social Development Index of the time from the onset of symptoms to diagnosis in Rio de Janeiro, Brazil (February-April 2020).

SDI (3.3\% vs. $1.6 \%)$, they recovered more often ( $25.1 \%$ vs. $14.5 \%)$. The time between the onset of symptoms until diagnosis was also significantly associated with the disease outcome $(\mathrm{p}<0.001)$. A higher mortality rate was recorded for patients with a diagnosis delay greater than eight days $(6.0 \% ; n=220)$ compared to delays of less than eight days $(2.3 \% ; \mathrm{n}=84)$. Patients diagnosed earlier ( $<8$ days) had higher recovery rates compared to those diagnosed later ( $41.1 \%$ vs. $7.4 \%)$ (Table 3).

Multivariate analysis of logistic regression showed that male patients had a higher odds of death from COVID-19 than female patients $(\mathrm{OR}=0.150$ [95\% CI, 0.051-0.440]; $\mathrm{p}=0.001$ ). The age groups that were statistically associated with death were: $70-79$ years $(\mathrm{OR}=1.495[95 \%$ CI, 1.121-1.994]; $\mathrm{p}=0.006), 80-89$ years $(\mathrm{OR}=$ 3.146 [95\% CI, 2.256-4.387]; $\mathrm{p}<0.001)$, and 9099 years $(\mathrm{OR}=5.100[95 \% \mathrm{CI}, 2.024-12.852] ; \mathrm{p}=$ $0.001)$. Patients from regions with a low SDI had increased odds for death from COVID-19 (OR $=1.833$ [95\% CI, 1.565-2.148]; $\mathrm{p}<0.001)$. Delay to diagnosis greater than eight days was also a risk factor for death $(\mathrm{OR}=3.537$ [95\% CI, 2.7694.519]; $\mathrm{p}<0.001)$. Results of univariate and multivariate analyses were similar (Table 4).

After conducting the mortality analysis (Table 4), the sensitivity analysis of the logistic re- 
Table 2. Results of multivariate and univariate analysis of time-dependent covariate Cox regression of the associated risk factors in the delay of the diagnosis of COVID-19 in Rio de Janeiro, Brazil (February-April 2020).

\begin{tabular}{|c|c|c|c|c|c|c|c|c|}
\hline \multirow{2}{*}{ Characteristic } & \multicolumn{4}{|c|}{ Univariate analysis } & \multicolumn{4}{|c|}{ Multivariate analysis } \\
\hline & HR & $-95 \%$ CI & $+95 \% \mathrm{CI}$ & $\mathbf{p}$ & HR & $-95 \% \mathrm{CI}$ & $+95 \% \mathrm{CI}$ & $\mathbf{p}$ \\
\hline \multicolumn{9}{|l|}{ Gender } \\
\hline Female & 1.000 & - & - & - & 1.000 & - & - & - \\
\hline Male & 0.867 & 0.760 & 0.989 & 0.034 & 0.846 & 0.739 & 0.968 & 0.015 \\
\hline Not informed & 0.668 & 0.356 & 1.251 & 0.207 & 0.788 & 0.418 & 1.486 & 0.462 \\
\hline \multicolumn{9}{|l|}{ Age (years) } \\
\hline $30-39$ & 1.000 & - & - & - & 1.000 & - & - & - \\
\hline $0-9$ & 0.566 & 0.250 & 1.282 & 0.017 & 0.642 & 0.283 & 1.458 & 0.290 \\
\hline $10-19$ & 2.183 & 1.665 & 3.160 & 0.019 & 2.559 & 0.777 & 8.429 & 0.112 \\
\hline $20-29$ & 1.209 & 0.871 & 1.679 & 0.025 & 1.184 & 0.852 & 1.647 & 0.015 \\
\hline $40-49$ & 1.021 & 0.797 & 1.309 & 0.008 & 1.124 & 0.875 & 1.446 & 0.036 \\
\hline $50-59$ & 1.022 & 0.776 & 1.347 & 0.037 & 1.147 & 0.867 & 1.519 & 0.033 \\
\hline $60-69$ & 1.140 & 0.846 & 1.536 & 0.009 & 1.266 & 0.932 & 1.720 & 0.013 \\
\hline $70-79$ & 1.170 & 0.828 & 1.654 & 0.034 & 1.200 & 0.840 & 1.713 & 0.016 \\
\hline $80-89$ & 1.206 & .818 & 1.777 & 0.005 & 1.160 & 0.773 & 1.739 & 0.007 \\
\hline $90-99$ & 1.464 & 0.638 & 3.358 & 0.041 & 1.762 & 0.771 & 4.027 & 0.019 \\
\hline Not informed & 3.081 & 0.587 & 16.162 & 0.183 & 1.426 & 0.340 & 5.987 & 0.628 \\
\hline \multicolumn{9}{|l|}{ SDI level } \\
\hline High SDI & 1.000 & - & - & - & 1.000 & - & - & - \\
\hline Low SDI & 0.759 & 0.649 & 0.888 & 0.001 & 0.721 & 0.614 & 0.847 & 0.000 \\
\hline \multicolumn{9}{|l|}{ Evolution } \\
\hline Recovery & 1.000 & - & - & - & 1.000 & - & - & - \\
\hline Death & 1.307 & 1.115 & 1.532 & 0.001 & 1.372 & 1.158 & 1.625 & 0.000 \\
\hline Active disease & 1.857 & 1.500 & 2.300 & 0.000 & 1.960 & 1.574 & 2.440 & 0.000 \\
\hline
\end{tabular}

Note: CI, confidence interval; HR, hazard ratio; SDI, social development index.

gression model of factors related with mortality was then performed by excluding patients with active disease who represented $43.1 \%(\mathrm{n}=1577)$ of the mortality analysis (table 4 ) and maintaining only recovered patients $(48.6 \%, \mathrm{n}=1775)$ and deaths from COVID-19 $(8.3 \%, \mathrm{n}=304)$. In general, the results of the sensitivity analysis (Table 5) were similar to the previous model (Table 4 ), however, significant increases in the magnitude of the effect (increase in Odds Ratio) of all factors associated with mortality were found in comparison with the model including patients with active disease (Table 4), as can be seen in Table 5 in supplementary material. In addition, the multivariate model of sensitivity analysis showed that ages between $40-49$ years $(\mathrm{OR}=3.226[95 \%$ $\mathrm{CI}, 1.561-6,668] ; \mathrm{p}=0.002), 50-59$ years $(\mathrm{OR}=$ 5.341 [95\% CI, 2.625-10.865]; $\mathrm{p}=0.000)$ and 6069 years $(\mathrm{OR}=13.280[95 \% \mathrm{CI}, 6.662-26.474]$; $\mathrm{p}=0.000)$ became factors associated with mor- tality odds due to COVID 19, which differs with data from the mortality analysis model including patients with active disease (Table 4), where these age groups were not associated with mortality odds of the disease, but it is the age groups from 70 years onwards that have been associated with mortality. The results of the multivariate model of sensitivity analysis were similar with the univariate sensitivity analysis (Table 5).

\section{Discussion}

We evaluated data on more than 3,500 patients diagnosed with COVID-19 in Rio de Janeiro, Brazil, for a period of two months, with a resulting mortality rate of around $8.0 \%$. Time from the onset of symptoms to diagnosis was approximately one week, with male patients, younger people, and those living in less developed regions 
Table 3. Evolution of COVID -19 according to patient characteristics in Rio de Janeiro, Brazil (February-April 2020).

\begin{tabular}{|c|c|c|c|c|c|}
\hline \multirow[b]{2}{*}{ Characteristics } & \multicolumn{3}{|c|}{ Disease outcome n (\%) } & \multirow[t]{2}{*}{ Total } & \multirow[t]{2}{*}{$\mathbf{p}^{*}$} \\
\hline & Recovery & Death & $\begin{array}{c}\text { Active } \\
\text { disease } \\
\end{array}$ & & \\
\hline Gender & & & & & 0.000 \\
\hline Female & $919(25.1 \%)$ & $122(3.3 \%)$ & $899(24.6 \%)$ & $1940(53.1 \%)$ & \\
\hline Male & $821(22.5 \%)$ & $182(5.0 \%)$ & $674(18.4 \%)$ & $1677(45.9 \%)$ & \\
\hline Not informed & $35(1.0 \%)$ & $0(0.0 \%)$ & $4(0.1 \%)$ & $39(1.1 \%)$ & \\
\hline Age (years) & & & & & 0.000 \\
\hline $0-9$ & $15(0.4 \%)$ & $0(0.0 \%)$ & $7(0.2 \%)$ & $22(0.6 \%)$ & \\
\hline $10-19$ & $13(0.4 \%)$ & $0(0.0 \%)$ & $3(0.1 \%)$ & $16(0.4 \%)$ & \\
\hline $20-29$ & $151(4.1 \%)$ & $4(0.1 \%)$ & $159(4.3 \%)$ & $314(8.6 \%)$ & \\
\hline $30-39$ & $416(11.4 \%)$ & $10(0.3 \%)$ & $399(10.9 \%)$ & $825(22.6 \%)$ & \\
\hline $40-49$ & $398(10.9 \%)$ & $32(0.9 \%)$ & $420(11.5 \%)$ & $850(23.2 \%)$ & \\
\hline $50-59$ & $315(8.6 \%)$ & $41(1.1 \%)$ & $251(6.9 \%)$ & $607(16.6 \%)$ & \\
\hline $60-69$ & $216(5.9 \%)$ & $68(1.9 \%)$ & $129(3.5 \%)$ & $413(11.3 \%)$ & \\
\hline $70-79$ & $121(3.3 \%)$ & $65(1.8 \%)$ & $82(2.2 \%)$ & $268(7.3 \%)$ & \\
\hline $80-89$ & $67(1.8 \%)$ & $73(2.0 \%)$ & $80(2.2 \%)$ & $220(6.0 \%)$ & \\
\hline $90-99$ & $6(0.2 \%)$ & $8(0.2 \%)$ & $15(0.4 \%)$ & $29(0.8 \%)$ & \\
\hline Not informed & $57(1.6 \%)$ & $3(0.1 \%)$ & $32(0.9 \%)$ & $92(2.5 \%)$ & \\
\hline SDI & & & & & 0.000 \\
\hline Low SDI & $919(25.1 \%)$ & $122(3.3 \%)$ & $899(24.6 \%)$ & $1940(53.1 \%)$ & \\
\hline High SDI & $529(14.5 \%)$ & $58(1.6 \%)$ & $331(9.1 \%)$ & $918(25.1 \%)$ & \\
\hline $\begin{array}{l}\text { Time between symptoms onset and } \\
\text { diagnosis (days) }\end{array}$ & & & & & 0.000 \\
\hline$<8$ & $1504(41.1 \%)$ & $220(6.0 \%)$ & $1555(42.5 \%)$ & $3279(89.7 \%)$ & \\
\hline$>8$ & $271(7.4 \%)$ & $84(2.3 \%)$ & $22(0.6 \%)$ & $377(10.3 \%)$ & \\
\hline
\end{tabular}

having longer delays in diagnosis. These results are similar to those presented in other studies published worldwide ${ }^{1,15-20}$.

Previous studies on the etiopathogenesis of viral infection and the clinical management of the disease demonstrated differences in the prevalence and severity of COVID-19 according to patients' gender, which may be an important risk factor for mortality ${ }^{21-23}$. Epidemiological data on gender are essential to understanding the distribution of risk, infection, and disease in the population, and the extent to which sex affects clinical outcomes comorbidities ${ }^{21,24}$. A report including 552 hospitals from 30 provinces in China, revealed that the majority $(58.0 \%)$ of patients with COVID-19 were males and also shows that patients of that gender are more likely to contract the disease $\mathrm{e}^{22}$. This may occur given the higher prevalence of previous chronic diseases in men that enable the virus to develop, and contribute to increased disease severity ${ }^{24}$. Additionally, studies evaluating other SARS caused by coronavirus suggest high levels of estrogen (more prevalent in women) as an important protective factor that may help to control the infection ${ }^{21,24}$. Moreover, women usually have a greater self-care in health when compared to men ${ }^{25}$, which may contribute to a more rapid perception of disease symptoms and, consequently, an earlier diagnosis. In this context, it is important to promote specific measures of prevention, surveillance, and greater intensive intervention for older men with comorbidities $^{21,24}$. Failing to integrate gender differences in COVID-19 surveys can neglect a key risk factor and possibly create or increase inequities in healthcare.

We also found the patients' SDI in Rio de Janeiro was an important variable for delays in diagnosis and a risk factor for mortality. Previous studies showed extensive socioeconomic in- 
Table 4. Results of multivariate and univariate analyses of logistic regression of risk factors associated with mortality from COVID-19 in Rio de Janeiro, Brazil (February-April 2020).

\begin{tabular}{|c|c|c|c|c|c|c|c|c|}
\hline \multirow[b]{2}{*}{ Characteristics } & \multicolumn{4}{|c|}{ Univariate analysis } & \multicolumn{4}{|c|}{ Multivariate analysis } \\
\hline & OR & $\begin{array}{c}-95 \% \\
\text { CI }\end{array}$ & $\begin{array}{c}+95 \% \\
\mathrm{CI}\end{array}$ & $\mathbf{p}$ & OR & $\begin{array}{c}-95 \% \\
\text { CI }\end{array}$ & $\begin{array}{c}+95 \% \\
\mathrm{CI}\end{array}$ & $\mathbf{p}$ \\
\hline \multicolumn{9}{|l|}{ Gender } \\
\hline Male & 1.000 & - & - & - & 1.000 & - & - & - \\
\hline Female & 0.110 & 0.039 & 0.310 & 0.000 & 0.150 & 0.051 & 0.440 & 0.001 \\
\hline Not informed & 1.066 & 0.935 & 1.214 & 0.341 & 1.003 & 0.875 & 1.149 & 0.966 \\
\hline \multicolumn{9}{|l|}{ Age (years) } \\
\hline $30-39$ & 1.000 & - & - & - & 1.000 & - & - & - \\
\hline $0-9$ & 0.475 & 0.192 & 1.176 & 0.108 & 0.566 & 0.224 & 1.431 & 0.230 \\
\hline $10-19$ & 0.235 & 0.066 & 0.830 & 0.024 & 0.281 & 0.078 & 1.005 & 0.051 \\
\hline $20-29$ & 1.098 & 0.847 & 1.424 & 0.481 & 1.091 & 0.838 & 1.422 & 0.518 \\
\hline $40-49$ & 1.155 & 0.954 & 1.399 & 0.141 & 1.211 & 0.995 & 1.474 & 0.056 \\
\hline $50-59$ & 0.943 & 0.764 & 1.163 & 0.582 & 1.032 & 0.832 & 1.279 & 0.777 \\
\hline $60-69$ & 0.928 & 0.732 & 1.175 & 0.534 & 1.115 & 0.872 & 1.425 & 0.385 \\
\hline $70-79$ & 1.236 & 0.937 & 1.629 & 0.134 & 1.495 & 1.121 & 1.994 & 0.006 \\
\hline $80-89$ & 2.323 & 1.690 & 3.192 & 0.000 & 3.146 & 2.256 & 4.387 & 0.000 \\
\hline $90-99$ & 3.899 & 1.571 & 9.674 & 0.003 & 5.100 & 2.024 & 12.852 & 0.001 \\
\hline Not informed & 0.625 & 0.401 & 0.972 & 0.037 & 0.822 & 0.509 & 1.327 & 0.422 \\
\hline \multicolumn{9}{|l|}{ SDI level } \\
\hline High SDI & 1.000 & - & - & - & 1.000 & - & - & - \\
\hline Low SDI & 1.628 & 1.400 & 1.894 & 0.000 & 1.833 & 1.565 & 2.148 & 0.000 \\
\hline \multicolumn{9}{|c|}{$\begin{array}{l}\text { Time between symptoms onset and } \\
\text { diagnosis (days) }\end{array}$} \\
\hline$<8$ & 1.000 & - & - & - & 1.000 & - & - & - \\
\hline$>8$ & 3.017 & 2.386 & 3.816 & 0.000 & 3.537 & 2.769 & 4.519 & 0.000 \\
\hline
\end{tabular}

equalities in access to healthcare in Brazil. In a study by Paim et al. ${ }^{26}, 76.0 \%$ of the people with high income stated that they consulted a doctor in 2008 for any clinical diagnosis, compared to $59.0 \%$ of those with lower salary ${ }^{26}$. On the other hand, a study published in The Lancet ${ }^{26}$ demonstrated that $93.0 \%$ of individuals who actually sought healthcare services in Brazil during this same period received proper treatment. That is to say, social inequalities in the use of services may be associated, among others, with patient behavior ${ }^{26}$. Individuals with low incomes may postpone the decision to seek healthcare services due to past negative experiences and the inability to miss work ${ }^{27}$.

The different regions of Rio de Janeiro vary in demographic and infrastructure characteristics. Residents in regions with a lower SDI are, usually, less literate, younger, and have limited access to basic sanitary services when compared to residents in regions with a higher $\mathrm{SDI}^{9,12}$. These determinants are often associated with causing several differences in various traits (e.g., prevalence, severity) of diseases among the population $^{28}$, now including COVID-194. Given this, it is critical that the government introduces further emergence measures, such as improving the healthcare infrastructure, to prevent the virus from spreading in these fragile areas. The current scenario also highlights the need to strengthen access to the Brazilian Unified Healthcare Sys$t^{2} \mathrm{~m}^{6}$, in addition to the importance of increasing investments in research, technology, and innovation to effectively combat the pandemic in the country ${ }^{15-20}$.

Finally, current data show that Brazil has the second-highest number of confirmed coronavirus cases in the world. At the same time, the country is ranked $19^{\text {th }}$ in diagnostic tests application for the population ${ }^{29}$. Until May 25, 2020, 
Table 5. Results of sensitivity analysis of the multivariate and univariate logistic regression model of the risk factors associated with mortality by COVID-19 in Rio de Janeiro, Brazil (February to April 2020).

\begin{tabular}{|c|c|c|c|c|c|c|c|c|}
\hline \multirow[t]{2}{*}{ Characteristics } & \multicolumn{4}{|c|}{ Univariate analysis } & \multicolumn{4}{|c|}{ Multivariate analysis } \\
\hline & OR & $-95 \%$ CI & $+95 \% \mathrm{CI}$ & p & OR & $-95 \%$ CI & $+95 \% \mathrm{CI}$ & $\mathbf{p}$ \\
\hline \multicolumn{9}{|l|}{ Gender } \\
\hline Male & 1.000 & - & - & - & 1.000 & - & - & - \\
\hline Female & 0.599 & 0.467 & 0.767 & 0.000 & 0.642 & 0.486 & 0.848 & 0.002 \\
\hline Not informed & 0.069 & 0.044 & 0.090 & 0.790 & 0.434 & 0.001 & 0.800 & 0.998 \\
\hline \multicolumn{9}{|l|}{ Age (years) } \\
\hline $30-39$ & 1.000 & - & - & - & 1.000 & - & - & - \\
\hline $0-9$ & 0.431 & 0.200 & 0.766 & 0.998 & 0.030 & 0.001 & 0.070 & 0.999 \\
\hline $10-19$ & 0.200 & 0.002 & 0.340 & 0.999 & 0.130 & 0.050 & 0.450 & 0.999 \\
\hline $20-29$ & 1.102 & 0.341 & 3.566 & 0.871 & 1.130 & 0.348 & 3.666 & 0.839 \\
\hline $40-49$ & 3.345 & 1.623 & 6.894 & 0.001 & 3.226 & 1.561 & 6.668 & 0.002 \\
\hline $50-59$ & 5.415 & 2.671 & 10.976 & 0.000 & 5.341 & 2.625 & 10.865 & 0.000 \\
\hline $60-69$ & 13.096 & 6.609 & 25.950 & 0.000 & 13.280 & 6.662 & 26.474 & 0.000 \\
\hline $70-79$ & 22.347 & 11.143 & 44.816 & 0.000 & 22.562 & 11.172 & 45.563 & 0.000 \\
\hline $80-89$ & 45.325 & 22.296 & 92.142 & 0.000 & 50.726 & 24.672 & 104.293 & 0.000 \\
\hline $90-99$ & 55.467 & 16.207 & 189.834 & 0.000 & 70.321 & 19.640 & 251.778 & 0.000 \\
\hline Not informed & 2.189 & 0.585 & 8.193 & 0.244 & 3.656 & 0.954 & 14.007 & 0.059 \\
\hline \multicolumn{9}{|l|}{ SDI level } \\
\hline High SDI & 1.000 & - & - & - & 1.000 & - & - & - \\
\hline Low SDI & 1.801 & 1.329 & 2.440 & 0.000 & 2.366 & 1.684 & 3.324 & 0.000 \\
\hline \multicolumn{9}{|c|}{$\begin{array}{l}\text { Time between symptoms onset } \\
\text { and diagnosis (days) }\end{array}$} \\
\hline$<8$ & 1.000 & - & - & - & 1.000 & - & - & - \\
\hline$>8$ & 2.119 & 1.597 & 2.811 & 0.000 & 1.436 & 1.040 & 1.983 & 0.028 \\
\hline
\end{tabular}

around 3,460 tests per million inhabitants were performed in the country, compared to 45,586 tests per million inhabitants conducted in the United States, and the 40,000 tests per million inhabitants in Germany and Italy. These data confirm the lack of tests carried out in Brazil, and that cases are underreported. It is estimated that one in 10 positive cases are reported ${ }^{30,31}$.

Our study has some limitations. Although we performed an analysis with a cohort of patients from one of the largest cities in Brazil, representing different socioeconomic levels, it may not reflect the reality from other regions. Some of these data may be underestimated, given the underreporting of cases. Other variables potentially associated with COVID-19 can be evaluated in further studies. The inclusion of patients with active disease in the analysis may represent a bias because some of these cases can die due the progression of the disease. Given some lim- itations from the original database (e.g. lack of information on patient's follow-up), further survival analysis were not possible.

\section{Conclusion}

Delays in diagnosis and risk factors for death from COVID-19 in Rio de Janeiro, Brazil were associated with male gender, age under 60 years, and patients living in regions with lower social development index, including favelas. Additionally, a delay between the onset of symptoms until diagnosis greater than eight days may increase mortality rates. These results highlight the continuous challenges to contain, mitigate, and control the disease in environments with scarce resources, including the lack of mass testing. Further preventive measures are still needed, especially for vulnerable groups. 


\section{Collaborations}

AF Cobre participated in conceptualization, methodology, investigation, software, formal analysis, writing, and original draft preparation. B Böger participated in visualization, project administration, formal analysis, writing, and original draft preparation. MM Fachi participated in formal analysis, software, writing, and original draft preparation. RO Vilhena participated in formal analysis, writing, and original draft preparation. EL Domingos participated in writing, review \& editing. FS Tonin participated in conceptualization, methodology, formal analysis, software, writing, review \& editing, investigation, and supervision. R Pontarolo participated in conceptualization, resources, writing, original draft preparation, funding acquisition, and supervision.

\section{Acknowledgments}

The authors express their gratitude for research funding to the CAPES (Coordenação de Aperfeiçoamento de Pessoal de Nível Superior).

\section{References}

1. World Health Organization (WHO). Coronavirus disease (COVID-2019) situation reports 2020. Geneva: WHO; 2020 Mar 16. Report No.: 56. [cited 2020 May 20]. Available from: https://www.who. int/docs/default-source/coronaviruse/situation-reports/20200316-sitrep-56-covid-19.pdf?sfvrsn=9fda7db2_6

2. Guan WJ, Ni ZY, Hu Y, Liang WH, Ou CQ, He JX, Liu L, Shan H, Lei C, Hui DSC, Du B, Li L, Zeng G, Yuen K, Chen R, Tang C, Wang T, Chen P, Xiang J, Li S, Wang J, Liang Z, Peng Y, Wei L, Liu Y, Hu Y, Peng P, Wang J, Liu J, Chen Z, Li G, Zheng Z, Qiu S, Luo J, Ye C, Zhu S, Zhong N, for the China Medical Treatment Expert Group for Covid-19. Clinical characteristics of coronavirus disease 2019 in China. N Engl J Med 2020; 382(18):1708-1720.

3. Rodriguez-Morales AJ, Gallego V, Escalera-Antezana JP, Méndez CA, Zambrano LI, Franco-Paredes C, Suárez JA, Rodriguez-Enciso HD, Balbin-Ramon GJ, Savio-Larriera E, Risquez A, Cimerman S. COVID-19 in Latin America: the implications of the first confirmed case in Brazil. Travel Med Infect Dis 2020; 35:101613.

4. Corburn J, Vlahov D, Mberu B, Riley L, Caiaffa WT, Rashid SF, Ko A, Patel S, Jukur S, Martínez-Herrera E, Jayasinghe S, Agarwal S, Nguendo-Yongsi B, Weru J, Ouma S, Edmundo K, Oni T, Ayad H. Slum Health: arresting COVID-19 and improving well-being in urban informal settlements. J Urban Health 2020; 97(3):348-357.

5. Wang C, Horby PW, Hayden FG, Gao GF. A novel coronavirus outbreak of global health concern. Lancet 2020; 395(10223):470-473.

6. Chen Y, Chan KH, Kang Y, Chen H, Luk HKH, Poon RWS, Chan JFW, Yuen K, Xia N, Lau SKP, Woo PCY. A sensitive and specific antigen detection assay for Middle East respiratory syndrome coronavirus. Emerg Microbes Infect 2015; 4(4):e26.

7. Meyer B, Drosten C, Müller MA. Serological assays for emerging coronaviruses: challenges and pitfalls. Virus Res 2014; 194:175-183.

8. Castro R, Luz PM, Wakimoto MD, Veloso VG, Grinsztejn B, Perazzo H. COVID-19: a meta-analysis of diagnostic test accuracy of commercial assays registered in Brazil. Braz J Infect Dis 2020; S1413-8670(20)30029-5.

9. Snyder RE, Marlow MA, Riley LW. Ebola in urban slums: the elephant in the room. Lancet Glob Health 2014; 2(12):e685.

10. Osório M, Melo LM, Versiani MH, Werneck ML. Uma agenda para o Rio de Janeiro: estratégias e políticas públicas para o desenvolvimento socioeconômico. Rio de Janeiro: FGV Editora; 2015.

11. Brasil. Ministério da Saúde (MS). Coronavírus Brasil. Painel de casos de doença pelo coronavírus 2019 (COVID-19) no Brasil pelo Ministério da Saúde [Internet]. Brasília: MS; 2020. [cited 2020 May 24]. Available from: https://covid.saude.gov.br/

12. Santos J, Pedro A, Praça H, Albuquerque H. Vulnerabilidade socioespacial a formas graves de Covid-19: uma análise intramunicipal na cidade do Rio de Janeiro, Brasil. Cad Saude Publica 2020;36(5):e00075720. 
13. Rio de Janeiro. Secretaria Municipal de Saúde (SMS/ RJ). Painel Rio COVID-19 [Internet]. Rio de Janeiro: SMS/RJ; 2020. [cited 2020 May 20]. Available from: https://experience.arcgis.com/experience/38efc69787a346959c931568bd9e2cc4

14. Cavallieri F, Lopes GP. Índice de Desenvolvimento Social - IDS: comparando as realidades microurbanas da cidade do Rio de Janeiro. Rio de Janeiro: Instituto Pereira Passos (IPP); 2008 Apr. [cited 2020 May 20]. Available from: http://portalgeo.rio.rj.gov.br/estudoscariocas/download/2394_\%C3\%8Dndice\%20de\%20 Desenvolvimento\%20Social_IDS.pdf.

15. Brasil. Ministério da Saúde (MS). Boletim Epidemiológico Especial COE-COVID 19. Brasilia: MS; 2020. [Report No 14].

16. National Center for Health Statistics - NCHS (US). Weekly Updates by Select Demographic and Geographic Characteristics: Provisional Death Counts for Coronavirus Disease (COVID-19). Center for Disease Control and Prevention; 2020 May 21 [cited 2020 May 24]. Available from: https://www.cdc.gov/nchs/nvss/ vsrr/covid_weekly/index.htm\#AgeAndSex.

17. Australia. Department of Health (DH). COVID-19, Australia: Epidemiology Report 16: Reporting week ending 23:59 AEST 17 May 2020. Sidney: DH, Communicable Diseases Intelligence; 2020 May 17 [update 2020 May 22; cited 2020 May 24]. Report No.: 16. Available from: https://doi.org/10.33321/cdi.2020.44.45.

18. Brasil. Ministério da Saúde (MS). Boletim Epidemiológico Especial COE-COVID 19. Brasilia: MS; 2020. [Report No 16].

19. Brasil. Ministério da Saúde (MS). Boletim Epidemiológico Especial COE-COVID 19. Brasilia: MS; 2020. [Report No 15].

20. Gao Q, Hu y, Dai z, Wu J, Xiao F, Wang J. The epidemiological characteristics of 2019 novel coronavirus diseases (COVID-19) in Jingmen, Hubei, China. medRxiv [Preprint]; 2020 May 21 [cited 2020 May 24]. Available from: https://doi.org/10.1101/2020.03. 07.20031393.

21. Wei X, Xiao YT, Wang J, Chen R, Zhang W, Yang Y, Lv D, Qin C, Gu D, Zhang B, Chen W, Hou J, Song N, Zeng G, Ren S. Sex Differences in severity and mortality among patients with COVID-19: evidence from pooled literature analysis and insights from integrated bioinformatic analysis. arXiv:2003.13547 [Preprint] 2020 Mar 30 [cited 2020 May 20]. Available from: https:// arxiv.org/abs/2003.13547

22. Zhao Y, Zhao Z, Wang Y, Zhou Y, Ma Y, Zuo W. Single-cell RNA expression profiling of ACE2, the putative receptor of Wuhan 2019-nCov. BioRxiv 2020.01.26.919985 [Preprint] 2020 Jan 26 [cited 2020 May 20]. Available from: https://doi. org/10.1101/2020.01.26.919985.
23. Cai H. Sex difference and smoking predisposition in patients with COVID-19. Lancet Respir Med 2020; 8(4):e20.

24. Sharma G, Volgman AS, Michos ED. Sex differences in mortality from COVID-19 pandemic: are men vulnerable and women protected? JACC Case Rep 2020; 2(9):1407-1410.

25. Laurenti R, Jorge MHPM, Gotlieb SLD. Perfil epidemiológico da morbi-mortalidade masculina. Cien Saude Colet 2005; 10(1):35-46.

26. Paim J, Travassos C, Almeida C, Bahia L, Macinko J. The Brazilian health system: history, advances, and challenges. Lancet 2011; 377(9779):1778-1797.

27. Mendes W, Martins M, Rozenfeld S, Travassos C. The assessment of adverse events in hospitals in Brazil. Int J Qual Health Care 2009; 21(4):279-284.

28. Riley LW, Ko AI, Unger A, Reis MG. Slum health: Diseases of neglected populations. BMC Int Health Hum Rights 2007; 7:2.

29. Worldometer. COVID-19 Coronavirus Pandemic [Internet] 2020. [cited 2020 May 2020]. Available from: https://www.worldometers.info/coronavirus/?utm campaign $=$ homeADemocracynow $(2020) \% 20$ dvegasl?

30. Reis RF, Quintela BM, Campos JO, Gomes JM, Rocha BM, Lobosco M, Santos RW. Characterization of the COVID-19 pandemic and the impact of uncertainties, mitigation strategies, and underreporting of cases in South Korea, Italy, and Brazil. Chaos, Solitons Fractals 2020; 136:109888.

31. Ribeiro LC, Bernardes AT. Estimate of underreporting of COVID-19 in Brazil by acute respiratory syndrome hospitalization reports. Belo Horizonte: UFMG; 2020.

Article submitted 16/06/2020

Approved 27/07/2020

Final version submitted 29/07/2020 